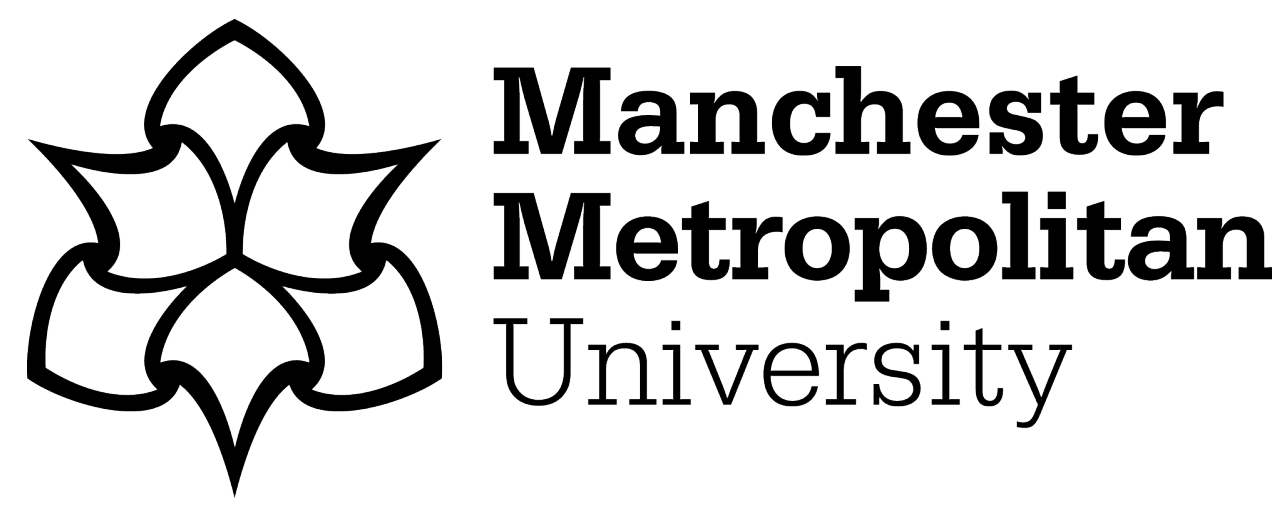

Solomon, YJ, Eriksen, E, Smestad, B, Rodal, C and Bjerke, A (2017) Prospective teachers navigating intersecting communities of practice: early school placement. Journal of Mathematics Teacher Education, 20 (2). pp. 141-158. ISSN 1386-4416

Downloaded from: https://e-space.mmu.ac.uk/594505/

Version: Accepted Version

Publisher: Springer Verlag (Germany)

DOI: https://doi.org/10.1007/s10857-015-9327-6

Please cite the published version 


\title{
Prospective teachers navigating intersecting communities of practice: early school placement
}

\author{
Solomon, Y., Erikson, E, Smestad, B., Rodal, C., \& Bjerke, A.
}

\begin{abstract}
An issue of particular concern in mathematics teacher education is the relationship between theory and practice, and the nature of university-school partnerships. We report here on results from a research project answering the call for a more systematic understanding of the practice learning context. The study focuses on the new Norwegian elementary teacher education programme and highlights the difficulties involved in connecting theory and practice and how prospective teachers may be supported in this respect. Focus group interviews involving 51 first-year prospective teachers and 25 teacher-mentors investigated early school placements, specifically prospective teachers' positions in the classroom as teachers of mathematics, and the ways in which the mentoring relationship supported their developing role. Taking a communities of practice perspective, we found that the idea of movement across intersecting and sometimes conflicting communities of practice is helpful in aiding our understanding of the difficulty of connecting theory and practice. Additionally, variations in mentoring styles and perceptions of prospective teachers' mathematics and pedagogic knowledge competencies play a part in some prospective teachers' difficulties in taking up a role as legitimate peripheral participant in the school. We conclude by considering ways in which prospective teachers might be better supported to cope with school placement.
\end{abstract}

Keywords: School placement, theory and practice, communities of practice, mathematics teaching

\section{Introduction}

The quality of teaching and hence teacher education is an international concern, particularly in the area of mathematics in the wake of international tests such as TIMSS and PISA. One particular issue concerns questions about how practice learning is organized, and the need to improve university-school partnerships with respect to the relationship between theory and practice. The research reported in this paper responds to calls for more systematic understanding of the practice learning context, following cross-national comparisons such as that conducted in Finland, England, Wales and Norway (SINTEF, 2008), Tatto, Lerman and Novotna's (2010) report on more than twenty countries, and the seventeen-country International Association for the Evaluation of Educational Achievement (IEA) (2012) report on mathematics teacher education.

The SINTEF (2008) report called for Norway to emulate and advance the UK model of collaboration between the university and the school, building on the earlier recommendations of the Norwegian Nasjonalt Organ for Kvalitet i Utdanningen (NOKUT) (2006) evaluation of teacher education for a more integrated relationship between theory and practice. As mathematics teacher educators in Norway, we are therefore interested in the ways in which teacher-mentors and our university college take responsibility during school placement for the connection between theory and practice. This paper therefore explores prospective teachers (PTs)' and mentors' perceptions of the connection between university learning about mathematics education, and learning from practice within early school placements. In 
particular, we focus on an aspect of this connection which is also identified by Gainsburg (2012): the tension between a common university focus on pedagogic concepts defined as the conceptual or theoretical principles underlying teaching and learning, versus a dominant school focus on teaching tools, practices and methods. In our particular context, universitybased teaching stresses pedagogic concepts such as the role of multiple representations in developing pupils' understanding of mathematics, and the importance of building on pupils' informal strategies; schools however, are more focused on concrete realizations of such pedagogical concepts as practical tools in the classroom. As we show in this paper, this tension can be seen to create particular challenges for prospective teachers as they navigate the boundaries between these intersecting communities of practice. In particular, variability in the ways that mentors take up their roles impacts on prospective teachers' responses to the demands of school placement, with implications for how they may be better supported to meet the challenge of development within a new system.

\section{Connecting theory and practice}

Frequently, the relationship between theory and practice is seen in terms of the difficulty for novices in multiple professions of putting theory into practice, where tacit practitioner knowledge plays a mediating role in a translation process or is even the target of learning itself, bypassing theoretical viewpoints altogether. However, in mathematics teacher education a further complexity arises in terms of a more or less explicit difference of opinion about what 'good' or 'effective' mathematics teaching looks like. Although university teacher educators tend to promote reform-oriented or 'connectionist' styles of teaching which are based on constructivist theories of learning, schools frequently enact a culture of traditional 'transmissionist' teaching prioritising the teaching of rules and algorithms. There are various explanations for this mismatch. While individual teachers often subscribe to reform-oriented teaching in theory, it can be difficult to sustain in the face of the demands of assessment, testing and accountability regimes. Thus Barnes, Cockerham, Hanley, and Solomon (2013) report that teachers struggled to put reform approaches into practice due to the pressure to produce easily measured evidence of pupils' progress in short time frames; it was easier in the short term to focus on rote-learned algorithms and 'teaching to the test'. In an earlier article (Bjerke et al 2013a) we report on a survey showing that in our context, mentors report significantly more reform-oriented views of mathematics than novice prospective teachers, suggesting that differences between universities and schools have more to do with culture or with historically embedded practice than with explicitly formulated views of mathematics teaching; indeed, focus group data from the same project indicated that mentors did not necessarily enact reform approaches in practice, even though they subscribed to these in theory (Bjerke et al 2013b). Expressing a common teacher educators' frustration that the practices they endorse are abandoned in school practice (Nolan, 2008), Nolan (2012) also reports on conflict between university support for inquiry-based pedagogies and instrumentalism in practice schools; she argues that this is not just due to the role of accountability and assessment in schools, but to the force of an educational habitus which is 
highly resistant to change: the power of cultural routines associated with teaching are such that 'every adult knows what teaching and learning should look like because he or she has spent thousands of hours as a student in school' (Bullock \& Russell, 2010, p. 93, cited in Nolan 2012). Arvold (2005) also uses the idea of habitus to argue that prospective teachers attend to different aspects of their teacher education programs and make sense of them differently, through the lens of their prior experience of being taught mathematics.

Gainsburg (2012) draws together the issues underlying the theory-practice problem in a study of teachers' perceptions of the barriers to implementing university-taught practices. She identifies (p. 359) three major issues: the structure of initial teacher education programmes in terms of the balance and timing of teaching general pedagogical concepts versus specific teaching methods; the challenges of putting connectionist or reform-based teaching into practice in comparison to transmissionist delivery; and the need for the novice teacher to bridge between the 'two worlds' of university and school contexts. Drawing on Grossman, Smagorinski and Valencia's (1999) distinction between conceptual tools (concepts, principles and frameworks that arise from education research to inform teaching) versus practical tools (specific goal-directed methods, physical objects, software, and so on which are more immediately useful in the classroom), Gainsburg notes that teacher education programmes tend to work on the assumption that laying a foundation of theoretical principles which can then be applied to practical situations is their best option, particularly given the impossibility of predicting exactly what situations prospective teachers will encounter in placement. However, research indicates otherwise: she cites Berliner's (1989) argument that the reverse is true, and that teachers abstract general principles from specific experience - "teachers must do before they understand" (p. 363); this view suggests that to expect prospective teachers to design their own conceptually-driven lessons is over-ambitious. Gainsburg's study supports this view: she focused on novice mathematics teachers with one to four years' experience who were graduates of a programme which explicitly endorsed reform-based practices (National Council of Teachers of Mathematics [NCTM], 2000) in mathematics teaching, such as asking questions or posing tasks with high cognitive demand, emphasising students' authority in making mathematical judgements, and encouraging pupils to make connections between topics and to use a variety of representations for the same problem (p. 361). Interviews with the novice teachers concerning their perceptions of the constraints on their employment of such practices identified that not only were they unable to apply a conceptual tool such as cognitive demand to a new setting, but they ideally needed to observe it used, then practice using it under guidance, before finally feeling prepared to implement it in their own classrooms.

Boaler's (2003) study of the differences in practice between three teachers all ostensibly adhering to a reform curriculum extends this view: despite their use of a reform curriculum approach, only one of the three could be seen to be enacting it. Noting the complexity involved in orchestrating students' engagement in a 'dance of agency' in their mathematics learning, she argues that a teacher education programme centred on presenting general principles misses the point that 
Dancers could not learn their craft by observing dance, or reading about successful dance. Teachers too need to learn their 'dance' by engaging in the practice of teaching. (p. 13)

In Norway, Kværnes (2013) picks up on the metaphor of teaching and dance in discussing how teachers may be supported to apply general principles. He describes the case of an optional course for in-service mathematics teachers designed to develop action-oriented teacher competencies by emphasising mathematics as activity. The final assignment consisted of planning, teaching, and reflecting back on a lesson in line with the philosophy of the course. One group chose a problem ("the border problem") from Boaler and Humphrey (2005) which is accompanied by a video from Humphrey's class, as well as the authors' discussion of the lesson, thereby giving the teachers a role model to emulate. Another group chose a problem on classification of geometric shapes. They drew on the same teaching, syllabus, and activities but had no specific role model to emulate. This group had difficulties with the double focus on the pupils' spontaneous contributions and on the mathematical objectives of the lesson. Kværnes proposes that, in order to learn the 'dance' of teaching, prospective teachers might need to start by performing basic steps and also following (as opposed to leading) in the dance. The power of good examples and the situatedness of teacher learning is also emphasised by Biesta (2012), who argues that possession of a set of competences is 'never enough'; the real issue for a teacher is making judgements about the use of such competences. Such judgement relies on becoming 'educationally wise', and this requires opportunities to see others acting wisely. For Biesta, this means that becoming a teacher relies on practising judgement, by doing it and learning from doing:

It is a conception of teacher education where the question of wise education judgements is constantly foregrounded, where the question of what it is that needs to be done is constantly posed and where students are constantly asked to engage with that question in relations to a broad conceptions of educational purpose and in light of the always unique characteristics of the situations they find themselves in. (p.48)

\section{Theoretical framework}

The perspectives on teacher education raised by Gainsburg and others in the previous section coincide with socio-cultural framings of learning as participation rather than acquisition, particularly communities of practice approaches (Wenger, 1998; 2000). Such approaches, which emphasise the centrality of social practices in human activity, and the movement of the learner from the position of novice and 'legitimate peripheral participant' (Lave and Wenger, 1991) to a fully engaged 'old-timer', fit the situation of the prospective teacher well. In entering a school community of practice as a prospective teacher on placement, the novice is explicitly positioned as a learner in a particular relationship with their mentor, there to develop competencies as a teacher. In Lave and Wenger's (1991) terminology, they could be, theoretically at least, legitimate peripheral participants in that they have a recognised role in low-risk and less skilled but nonetheless useful work in the practice, learning from experts 
and increasing their competencies towards more central and demanding tasks. In terms of Wenger's (1998) three 'modes of belonging' of engagement (full participation characterised by active negotiation of meaning), imagination (reflection on a practice and one's position in it) and alignment (coordination with and adherence to the norms of a practice), we might expect alignment to be dominant at this time, since it draws on common patterns of action which may be especially salient to the newcomer, accentuating standards which "propose broad systems of styles and discourses through which we can belong" (Wenger, 1998, p. 180). However, imagination in the sense of reflection may make an important contribution to learning; it involves an awareness of actions as part of historical patterns and potential future developments, of others' perspectives and of other possible meanings. It is "a process of expanding our self by transcending our time and space and creating new images of the world and ourselves" (p. 176). It therefore involves a positioning of self with respect to our own and other practices:

... using imagination to gain a good picture of the context of one's actions can help in fine-tuning alignment because one understands the reasons behind a procedure or an agreement. (Wenger, 2000, pp.228-9)

In early placements, which are the focus of this paper, prospective teachers may be most concerned with 'getting by': coping with a new system may be a question of pure alignment with its practices. Schools as communities of practice have implicit or explicit rules and norms to which their members are held accountable, and they draw on a 'shared repertoire of communal resources - language, routines, sensibilities, artifacts, tools, stories, styles' (Wenger, 2000, p. 229) which used 'appropriately' indicate competence. But in addition to their 'apprenticeship' to their mentor, school placement also introduces a complexity for prospective teachers in that they must navigate the intersection between the university and school communities of practice, with their overlapping but also different value systems and rules of engagement. In the context of school placement, the boundaries around and between these practices are particularly salient:

At the boundaries, competence and experience tend to diverge: a boundary interaction is usually an experience of being exposed to a foreign competence. ... if the distance is too great, not much learning is likely to take place...' (p. 233)

As Wenger suggests, boundary interactions are not necessarily negative: boundaries between communities which are 'in close tension' (p. 233) can promote critical reflection and new learning, and, as we shall see, reflection plays a part for some prospective teachers. But as Gainsburg points out, it is often the case that prospective teachers' movement from the university to the school during practice placements can be a difficult process of straddling 'two worlds', as Brown and Borko (1992) put it. When teaching practices promoted by the university differ drastically from those promoted in schools, as with reform versus traditional teaching, new teachers seem likely to cope with the tension by aligning heavily with the school, and placing less value on what they learned at university (Brown and Borko, 1992). In other words, the novice teacher is pressed into adopting the practices and beliefs of the old-timers in the community of practice of the school - that is, they must align with the 
practices of their host school, with little room for reflection.

In our particular context, tensions between reform and traditional pedagogies, and concepts versus methods create a boundary which prospective teachers must work across. In this paper, we draw further on the communities of practice framework to analyse how prospective teachers in the first year of their training experience and negotiate their novice status in the school, and the role of mentors as 'old-timers' in their training. Their experience is framed by the tension between methods and concepts which characterises the intersection between university and school communities of practice. We consider the extent to which prospective teachers can be seen as legitimate peripheral participants in the school community of practice, and the nature of their modes of belonging in it.

\section{The University College context}

In the teacher education programme for elementary teachers in grades 1-7 (age level 6-13), the 30 credits compulsory mathematics course spans over two years. The mathematics teacher educators promote and model reform-oriented teaching through a combination of mathematics and mathematics pedagogy. The academic level of the mathematics involved is predominantly at grades 1-7, and no higher than tenth-grade. Typically, a mathematics session is aimed at a specific mathematics topic, and general concepts (conceptual tools) are immediately illustrated with tasks in that specific topic, in this way providing prospective teachers with an opportunity to observe the teacher educator model the use of the conceptual tool (for example, coordinating the contribution of the groups into a class discussion). Practical tools in form of a concrete lesson plan with its accompanying strategies, use of specific representations, and so on, are also provided.

Prospective teachers have six weeks of school placement during their first year. Although the course content is intended to be consistent with what they will encounter in placement, there is a high likelihood that they will meet a topic that they have not yet covered in the university college. However, having been taught both practical tools and applications of conceptual tools for the topics discussed during the course, there is an expectation that they will be able to apply these tools in new contexts. For example, during the first year the course covers addition and subtraction, on the assumption that prospective teachers who have to teach multiplication and division in school placement will be able to see analogies, and realize that conceptual tools in the form of general principles - such as the role of multiple representations and building on pupils' informal strategies before introducing algorithms - are just as valid in the new situation. Equally, practical tools such as strategies for creating open tasks in multiplication are similar to the strategies in addition. According to Gainsburg (2012, p. 363), this is a concept-first teacher education model, indicating that it expects 'generativity', a concept coined in mathematics by Franke, Carpenter, Levi, and Fennema (2001, p. 655) to describe one's ability 'to learn new topics and solve new and unfamiliar problems' as opposed to only being able 'to solve problems explicitly covered by instruction'. 
Every year of the programme, prospective teachers are placed in schools in groups of up to four, mentored by a teacher at that school, observing and teaching the mentor's class. The mentor is an experienced teacher chosen by the school, and most have taken extra courses in mentoring. There are several meetings each year where mentors and university college teacher educators meet to discuss placement plans. In the first year, prospective teachers are placed in grades 1-4; age level 6-10, for 30 days, with two weeks in the autumn semester and the remaining four in the spring semester. In the autumn placement, prospective teachers spend most of their time in the classroom observing their mentor teach and at times assisting. During the spring placement the group begins to teach in class, planning lessons together and observing each other. A university-based teacher educator spends one day in the school, observing the group, participating in reflections, and discussing progress with the mentors.

In this study, we focus on the experience of early placement, studying prospective teachers in their first year spring placement. This is clearly a point in time when they are likely to find reform pedagogy most challenging in terms of its demands on subject and pedagogical knowledge, lesson planning, and contingent responses in the classroom (Windschitl, 2002). It is also a first major point of contact with a different system which sets the scene for later placements and expectations. Looking in detail at this important placement enables us to understand not only the roots of prospective teachers' ways of coping with intersecting communities of practice, but also the early impact of the tensions between theory and practice. In what follows, therefore, we address the following research questions:

1) How do prospective teachers experience the relationship between theory and practice across intersecting communities of practice in their first school placement?

2) How do variations in mentoring styles affect prospective teachers' opportunities for legitimate peripheral participation?

3) How do prospective teachers negotiate different modes of belonging as they cope with a new system?

\section{Methodology}

In the spring of 2012, we conducted five focus group interviews with a total of 25 first-year prospective teachers as well as two focus groups with a total of fourteen teacher-mentors. In the spring of 2013, we held a further five focus group interviews with a total of 26 first-year prospective teachers as well as three focus group interviews with a total of eleven teachermentors. All prospective teachers on the programme and all mentors were asked to volunteer, and all who volunteered were interviewed. Focus groups were conducted on campus, and were conducted by the four Norwegian authors, who are all mathematics teacher educators on the programme. In order to reduce potential problems of power imbalance, focus groups with prospective teachers were composed so that no student was in a group facilitated by a teacher educator responsible for their placement supervision or their teaching on the programme.

The focus group discussions covered the following four main questions and prompts for prospective teachers: 
- Tell us about the mathematics teaching you have been doing in your placements what lessons have you been involved in?

- How do the mentors support what you are doing? (What sort of advice do they give you? How do you use their advice?)

- What are you learning about teaching mathematics in your placements? Is it different from your expectations before you started school placement? (Can you give an example?)

- Are there any challenges or problems for you in your placements? (Can you give examples? Why do you think these challenges/problems arise? Do you think there is any way that they could be avoided?)

The mentor focus groups covered four parallel questions, seeking their views on the kind of mathematics teaching prospective teachers had been doing in their placements, the ways in which they supported them, what prospective teachers learned about mathematics teaching in placements, and the challenges they faced. We also included an additional fifth question:

- What are the challenges or problems for you as mentors in this situation? (Can you give examples? Why do you think these challenges/problems arise? Do you think there is any way that they could be avoided?)

The focus group data were transcribed in full in their original language (Norwegian) and analysed in two stages. The first stage of data-driven analysis was carried out through a process of reading and re-reading the transcripts to identify recurring themes in what students told us about their experiences. Bearing in mind the issues identified by Gainsburg as barriers to novice teachers' implementation of the practices emphasized by the university (the balance between concepts and methods, the difficulty of reform teaching and the two-worlds paradigm), we looked for those factors which the prospective teachers and their mentors identified as obstacles, but also for organizational issues that might reduce their learning opportunities in school placement, as well as for indications of how they navigated their roles at the intersection between communities of practice. We identified three main issues:

- A general concern with how well equipped prospective teachers were in terms of a tension between conceptual tools versus practical tools;

- The nature and extent of help that prospective teachers received from the mentors in terms of how well this supported their development as teachers;

- Difficulties in enacting the practices endorsed by the university in the school setting in terms of system-wide issues such as concerns with teachers' accountability for pupils' progress.

Having identified these issues, we moved to a holistic reading of the data which aimed to understand what lay behind them, and the connections between them. To ensure validity, each set of transcripts was analysed by at least two authors and later compared to reach agreement. This subsequent analysis utilised concepts from our theoretical framework to describe and explain prospective teachers' experience of their school placement. In particular, it enabled us to understand the nature of their experience of intersecting communities of 
practice with differing values and concerns, the ways in which mentors supported their developing practice and their status as legitimate peripheral participants, and the ways in which they negotiated modes of belonging within a new, often diverging, system. Our analysis in the next section is organised accordingly.

Data chosen for this paper were translated into English by the authors, who include both native Norwegian and native English speakers, with the aim of capturing sense in plausible English rather than literal translation (for example, metaphors were not translated literally where these would not make sense in English). Translation for these purposes is complex and appropriate translations were extensively discussed between the authors.

\section{Analysis}

As indicated above, prospective teachers might be seen as legitimate peripheral participants in the school community of practice, and their mentors as having particular 'old-timer' roles. At the same time, the prospective teachers were participants in the university college system, in an explicit learning relationship with 'old-timer' teacher educators. They were in this sense working across intersecting communities of practice with varying degrees of overlap and tension, with a main aim in placement of succeeding as a (novice) teacher. The following analysis therefore addresses each of our research questions in turn, focusing on their experience of the relationship between theory and practice across intersecting communities, variations in mentoring styles as support for legitimate peripheral participation, and modes of belonging.

\subsection{Unpacking the problem: How do prospective teachers experience the relationship between theory into practice across intersecting communities of practice?}

Analysis of the focus group discussions with both the prospective teachers and their mentors reflected issues identified in the literature which cluster around the problem of putting theory into practice, and the tension between conceptual tools versus practical tools as preparation for teaching. Prospective teachers' accounts of their placement experiences ranged from not seeing any connection between university preparation and placement practice at all, to more elaborated views concerning a lack of practical tools, a lack of subject-matter knowledge, a lack of opportunities to experiment (as opposed to following a dictated plan), the force of school norms, and so on. The perception of no connection at all is illustrated here:

I feel that what we learn here [at universitycollege] and what we learn in school placement does not fit together at all. I feel that I have not learned anything here that I have taken with me into school placement. (...) I feel that what I know about maths and teaching maths is what I learned from my mentor in school placement.

More frequently, prospective teachers gave more detailed accounts of the challenges they faced; they felt that their university teaching was too general and did not provide them with the means of teaching particular concepts. Berliner's (1989) call for teacher education to provide scripted lessons rather than general principles is echoed by some of the prospective teachers: 
It's the fact that you need twenty different ways to explain the same thing. In the fourth class about $1000 \mathrm{~g}=1 \mathrm{~kg}$, you run out of ideas. What can be a new approach? How else can we illustrate it? What kind of exercises shall we give them this time? There are fewer and fewer ideas in the toolbox.

In general, prospective teachers felt safer in this early placement when they felt they were armed with a 'toolbox', which perhaps enabled them to align more closely with the school community of practice and to perform the role of teacher. As novices, they felt that they lacked the competencies required to participate in the practice of teaching in school. Mentors also reported on prospective teachers' demands for help with specifics, a clear expression of lack of generativity (Franke et. al, 2001) in their learning of mathematics pedagogy:

They tend to stress a lot if we come to something not taught at university 'We haven't covered that yet!' (...). They feel reassured when the topic is familiar from [the university college].

Some prospective teachers' comments indicated that they recognised that they needed to experiment and use general pedagogic principles, perhaps in a more reflective move towards their future roles. This could be hampered, though, by school norms which demanded a more unquestioning alignment in terms of a fit with local practices:

The school we are placed at has a very clear plan they use and has a lot of types of models they have used for several years, so we don't feel we have much to say when we come...

This observation may have been a reflection of other school constraints which emerged in the mentors' focus groups: despite their willing investment in the training partnership (see Bjerke et al, 2013a), mentors were equally bound by the norms and competencies of the school community of practice, with consequences for their support for prospective teachers as legitimate peripheral participants, as we show in the next section.

Perhaps sensitive to mentors' concerns about their level of competency in the shared enterprise of achieving progress for their pupils, prospective teachers often suggested that they lacked appropriate mathematics knowledge, and that this prevented them from putting theory into practice in the school since they were unprepared for contingent action:

Since it is such a long time since we had it [mathematics], you become insecure as a teacher, because you're insecure about your expertise in maths, not in teaching mathematics, but maths as a subject, as a task...

...we know the theory, but we haven't been in schools and tested and felt things ourselves... So the preparations we do before [the lessons] are not to write the lesson plan, because we sort of know how to do that, but simply to prepare for the maths questions coming.

Mentors also expressed direct concerns about subject knowledge:

I can see there are considerable differences between them [PTs] in mathematics. 
Many of them don't actually understand decimal numbers. They lack the most elementary understanding in mathematics, for instance regarding decimal numbers.

One mentor pointed out the obvious difficulties in implementing the university-promoted student-centred teaching in such circumstances:

It shows when they attempt to understand pupils' reasoning, when kids explain their solutions. I often find that prospective teachers are unable to follow the arguments. It is for sure a matter of training, too, but I believe it says something about their basic number sense and mathematics ... I need to intervene because they just stand there like question marks, and the kids start to wonder if what they said was wrong - and it usually isn't.

There are many reasons, then, why prospective teachers do not feel equipped for the tasks of this early teaching practice: translating pedagogical theories and examples from one area into another is perceived to demand subject matter knowledge and concrete "tools" that they do not have. Furthermore, their perception of their lack of competencies for participation in the shared enterprise of the school is also shared by the old-timers who are mentoring them. It appears that this perception acts as a barrier to an identity of legitimate peripheral participant on the part of prospective teachers and to mentors' support for their involvement as such. We explore this issue in greater detail in the next section.

\subsection{Legitimate peripheral participation? Variation in mentoring styles}

The extent to which prospective teachers are able to take up a role of legitimate peripheral participant in the school community of practice depends on mentoring styles: we found variation in how far they were allowed to develop and enact their own teaching practice ideas versus being required to do no more than mimic the teacher. Alongside these differences we also identified variations in the quality of the feedback prospective teachers received as more or less supportive of development. As we have seen in the previous section, mentoring styles seemed to be influenced by the mentors' opinions of prospective teachers' subject knowledge, providing the main underpinning of their empowerment as legitimate peripheral participants (Lave \& Wenger, 1991, p.36).

The tension between the differently valued competences and practices of the communities of university and school is visible in variations within the types of support that mentors provide for prospective teachers, ranging from instructing them to merely copy, through supported experimentation, to the opposite extreme of giving no guidance at all. Prospective teachers were critical of both ends of the spectrum:

Our mentor is not very good, she just gives us a finished lesson plan that we have to follow exactly. So it's as if she has the class, just that we execute the plan.

Our mentor rarely has suggestions about what we could do. We asked for that but she says that, no, we need to just try things out and see how it goes.

It is hard to imagine how a "dance of agency" can be supported (Boaler, 2003) in either a 
situation in which there is no freedom at all or one in which there are no "rules" to follow, and hence no joint participation in the shared community enterprise of developing teaching.

Mentors' own reports reflected similar differences in approach. This novice mentor suggests that prospective teachers should watch and copy:

... I haven't done this so much, I haven't had many students [PTs] in practice [placement]. ... We'll do subtraction with regrouping next week. And we agreed that I would introduce the new topic, and they can have a go later on so that we are approximately on the same track.

As we have noted above, mentors expressed concern about prospective teachers' mathematics knowledge, and this linked to the amount of responsibility they were willing to give them. They felt that they needed to 'protect' children from their errors, particularly in mathematics. Despite what they say about supporting prospective teachers' learning, they were anxious that mathematics lessons shouldn't go wrong:

... I think it's great with students [PTs], but I also need to get the pupils through...

... I explain to them [PTs] why it's important they do it right in the first place - it is vital in mathematics. And I am the one responsible both for my pupils' learning, and for giving prospective teachers opportunities to experiment. At times I feel that mathematics as a subject is more vulnerable...

This approach appears to have been exacerbated when prospective teachers were seen as weak; mentors saw a lack of subject and pedagogic knowledge as a problem:

Three of them [the prospective teachers] are very weak. But then we just sort of gave them the teacher's textbook and told them: here is a very good description on how to encourage pupils' participation in class discussion...

In contrast to this kind of controlling guidance, other mentors reported that they encouraged prospective teachers to experiment as the only way to learn, and not be put off by failure:

...I encourage them to experiment as much as possible. Even if something goes completely wrong, that's fine. That's not what determines if you pass or fail. It's a good experience to have, whether the outcome is positive or negative...

Others, however, gave more structured guidance, sometimes in ways which can be seen as supporting legitimate peripheral participation in terms of giving general advice which enabled prospective teachers to develop both competency and their own professional approach. Here, a mentor makes the point that she tells prospective teachers early on in placement that there are many ways to teach a topic:

They often observe me teaching in the start of the school placement. 'Many roads lead to Rome!', I tell them. 'The road I choose doesn't have to be the right road'.

Some prospective teachers talked about having a free hand in lesson preparation, with feedback from the mentor on their choices: 
Our mentor doesn't give us material for the lessons. We read on the internet, and in the teacher's guide and in the textbooks and then we get feedback from the mentor on what might be most relevant. For the most part we just experiment.

Feedback was important to prospective teachers in terms of how it positioned them as developing teachers; some felt that feedback could be unhelpfully positive:

PT1: We don't get much concrete feedback from our mentor, just that what we do is good.

PT2 : Maybe it is good.

PT1: Yes, right... [They all laugh sarcastically]

We would argue that neither over-positive nor over-critical feedback treats prospective teachers as legitimate peripheral participants, as neither helps them to improve. Indeed they themselves were aware of this; for them, constructive feedback assisted reflective practice:

In maths I wouldn't have managed to get anywhere without feedback from my mentor. The first time I taught the whole class, all 28 kids together, I rushed through it. Of course, I did notice that it was always the same ten who had their hands up. I was always very quick to call on them to answer. I was then advised to take my time, wait, and be very thorough since the other 18 kids never got a thing out of it. So I tried it next time. I was told to try it, I hadn't thought of it myself. I'm so inexperienced.

There was corresponding evidence that some prospective teachers were developing independence of judgement on the basis of advice from mentors:

We have advice that comes both before and after teaching, but I only follow the advice if I am comfortable with it, and I think it is good advice, and if I don't use the advice then I give a reason why. ... I follow the advice [the mentor] gives as long as it comes naturally.

They also talked about learning from each other rather than from the mentor. Here, a prospective teacher talks about how her group works around lack of support from a mentor:

What I really wish I had is concrete examples of what one could do in specific cases. Our mentor is very keen on us proposing our own solutions. We are four very reflective girls in my group and we discuss each class immediately after it ends, even if he [the mentor] doesn't have time for it then. But we don't get much "This is what I would have done", like you say your mentor suggests that here you can do this, and this works well. This is what is lacking, learning from the mentor, because in a way we learn from each other [in the practice group], we don't learn from our mentor.

In these patterns of varying support for the development of competencies, we can see how some prospective teachers are 'scaffolded' in their developing practice, while others are not. For Lave and Wenger (1991) legitimate peripheral participation means involving newcomers in tasks which contribute to the joint enterprise, but are considered to be within their range of 
competence - there is limited risk attached to their involvement in this way. When mentors' opinions of prospective teachers' knowledge is low, this may influence the tasks they are given. At times, they are only permitted to copy their mentors' teaching, and this tendency is strengthened by the fear that pupils will not learn enough mathematics. Other prospective teachers are given free rein to experiment, which could be seen as anything but "low-risk", including the possibility of something going "completely wrong" as one mentor put it. As Lave and Wenger point out, this kind of variation makes the difference between empowerment and disempowerment for developing teachers:

As a place in which one moves toward more intensive participation, peripherality is an empowering position. As a place in which one is kept from participation more fully - often legitimately, from the broader perspective of society at large - it is a disempowering position. Beyond that, legitimate peripherality can be a position at the articulation of related communities. In this sense, it can itself be a source of power or powerlessness, in affording or preventing articulation and interchange among communities of practice. (1991, p.36)

\subsection{Modes of belonging: coping with a new system}

As we have noted, prospective teachers face challenges in putting theory into practice which are supported to a greater or lesser degree by variations in mentoring styles and their corresponding positioning as legitimate peripheral participants. As they cope with the demands of their entrance into the school community of practice, we see examples of different modes of belonging (Wenger, 1998) which may be linked to degrees of empowerment: while many prospective teachers express identities of alignment, we can also see elements of imagination and engagement in their accounts.

As we have seen, there is pressure on some prospective teachers to align strongly with the practices of the school; the need for accountability in terms of pupil progress is clearly one such pressure. On a number of occasions, they identified specific issues where there was a clear disagreement between theory and practice and took a position on the issue. Some aligned with the school, dismissing the general principles learned at university as disconnected from the reality of the classroom, reminiscent of Brown and Borko's (1992) observations on the two-world paradigm:

At university college you are told to avoid ability grouping, since in mixed ability groups the strong ones lift the weaker ones. I started believing it, but in school placement you discover that that there is no cooperative learning, the weak ones just copy the answers off the strong ones. It works better with ability grouping, it is easier. The university has such a gilded image of how pupils behave... [Laughter]

We can see this attempt at a rational argument for choosing to endorse the school practice and rejecting the theory presented at university as indicative of these particular prospective teachers' way of coping not only with their under-developed pedagogic knowledge and competencies, but also with their novice status in the school. As we have noted above, strong 
alignment with the practices of the host school is a potential coping strategy when moving across communities of practice which may be experienced as heavily bounded.

However, other prospective teachers commented critically on their placements. One might argue that these students are working towards a position of negotiators of meaning in the practice, and hence their belonging to the community can be seen as engagement. In one case a group of prospective teachers experienced extreme pressure to align, and were asked to follow to the letter all lesson plans written by the mentor. When the pressure was briefly lifted, and they were given freedom to experiment on the day the university college teacher educator visited, they seized the opportunity to plan an inquiry-based lesson inspired by their course, although they knew that this practice diverged from their mentor's:

Our mentor proposed that we write all number bonds to 10 on the board, and the kids could $\mathrm{cram}^{1}$ them. But $I$ gave them a rod with 10 multilink cubes that they partitioned. It worked very well! I guess our mentor is just not a fan of manipulatives...

Even when their lack of power means that they are not in a position to negotiate meanings, some prospective teachers show an imaginative mode of belonging in their relationship to the community. They are able to be reflective about the overall situation:

Being in school placement feels a bit like being on a training bike (...). You're really only there to get the experience to hook the theory on, and if you find any pegs that fit (...), that is awesome. But it's mostly there just to get warmed up, actually.

As newcomers, prospective teachers are aware that they lack many of the resources and competencies that are valued in the school community of practice. Even so, we see examples that they may not only align to the new community of practice, but may also engage and imagine. This may be a sign that at least some of the resources they have brought from the university community of practice are of sufficient "close tension" to make their experience of boundary crossing useful as a site of reflection.

\section{Conclusion: understanding and supporting movement across bounded communities of practice}

For prospective teachers, early school placements can be a difficult time, where they have to negotiate their role in a new community of practice with very limited resources. Studying this early experience sheds light on aspects of school placement which are also present - although less prominent - at later stages in teacher education, bringing them into sharp relief and drawing attention to issues of boundary crossing which remain even when teachers are newly qualified, as Gainsburg's (2012) study illustrates. Our aim in this paper was to explore the relationship between theory and practice in early school placement through an analysis of the ways in which prospective teachers were positioned in the classroom as teachers of mathematics, and the nature of the mentoring relationship as support for their developing

\footnotetext{
${ }^{1}$ The word "cram" ("pugge" in Norwegian) is a slang word with negative connotations. It is unlikely that the mentor used this word, and we interpret its use here as indicative of the prospective teacher's way of registering opposition.
} 
role. Our data suggest that the general problem of theory into practice, and the more specific one identified in work such as Nolan's of prospective teachers' apparent failure to employ the reform pedagogy taught at university, can be understood more clearly in terms of their movement across intersecting and sometimes conflicting communities of practice, and the role of mentors in supporting this movement.

One way in which mentors can assist with prospective teachers' on-going transition into the community of practice of teaching is by providing constructive support for them to experiment and learn from their mistakes, as one of our mentors notes above. The importance of this aspect of the relationship between the mentors and the prospective teachers is underlined by our finding that there was considerable variation in mentoring styles, with the result that some prospective teachers were unable to even approach a role of legitimate peripheral participant. Some mentors appeared to demand an alignment with school practices which was hard to resist. Others encouraged experimentation, but as the prospective teachers' comments suggest, this was not helpful without constructive critical feedback. Where this kind of support was available, or where advice was given but alignment was clearly not demanded, prospective teachers were able to develop an engaged stance, moving towards a role of reflective practitioners. Our theorising thus enables us to understand why some of the practical concerns noted by Gainsburg (2012) and also our informants arise, and how our prospective teachers negotiated these issues. A concepts-first teacher education programme such as ours, which implicitly assumes that prospective teachers can be equipped with competencies which they can then put into practice, means that the role of mentors is then crucial. Our data show that mentors need to strike a balance between on the one hand allowing prospective teachers to experiment, possibly drawing on ideas from their university courses, and on the other hand validating their efforts as fitting into the community of practice of teachers, by providing feedback that enables them to reflect on their emerging practice. In our study, prospective teachers seem similarly unhappy both if they are given free rein (expected to be able to translate pedagogical principles into concrete teaching on their own) and if they are given ready-made scripts by their mentors (expected to teach without thinking about the pedagogical principles). As Boaler (2003) argues, performing a "dance of agency" necessitates both freedom and rules if prospective teachers are to be supported in their development as reflective practitioners.

Furthermore, our findings indicate that prospective teachers feel that they can benefit not only from evaluation of their own teaching by mentors, but also from witnessing and discussing mentors' judgments (in their roles as teachers), on specific situations --“"This is what I would have done". As Gainsburg (2012) and Berliner (1989) recognise, prospective teachers need to observe as well as do before they understand; they want to see and reflect on 'the practice of good judgement', as Biesta (2012) suggests. This is in keeping with Lave and Wenger's (1991) account of legitimate peripheral participation as becoming a member of a community of practice with explicitly shared goals and a shared repertoire. However, the nature and extent of feedback prospective teachers get from mentors may suggest that they are not always regarded as legitimate peripheral participants in this sense. When mentors are not 
critical at all, they do not hold the prospective teachers accountable to the rules and norms of the system, making it impossible for them to even align. When mentors are over-critical, it may be because they do not regard the prospective teachers in their charge as having the requisite skills to even begin to participate in their common goals.

These tensions at the intersection between the 'two worlds' (Brown and Borko, 1992) of university and school practices go some way to explaining the common observation (Gainsburg, 2012) that prospective teachers are not always able to develop the kind of pedagogies that are advocated at the university college. One issue to take into account, clearly, is the pressure felt in some schools to achieve good results in mathematics. Some mentors express anxiety about the quality of children's learning, particularly in mathematics, unless they take a more controlling role with their mentees. This is particularly the case when prospective teachers are seen as weak, either in terms of their pedagogic knowledge or their subject knowledge. Another issue illustrated in our data is a perceived mismatch between the 'idealized' views of teacher educators versus the 'reality' of the classroom, for example regarding the practice of ability grouping in mathematics which is rejected by the teacher educators on the basis of research and theory but embraced in schools as a practical necessity. Both result in a potential exclusion of prospective teachers from legitimate peripheral participation in the school's practices.

Clearly, our influence on what mentors do is necessarily limited. However, our findings do suggest some implications for practice:

- Mentors' perceptions of prospective teachers as having limited knowledge are an important factor in the placement experience. Interventions designed to make mentors more aware of what prospective teachers have learned at university could be helpful, in addition to discussion of how mentors could provide constructive support when knowledge gaps inevitably arise.

- Prospective teachers in our study expressed a need to feel confident that they were well equipped to teach. Kværnes' (2013) example of supporting prospective teachers by providing opportunities to model their actions on those of more experienced teachers such as those appearing in Boaler and Humphreys' (2005) video work suggests a possible remedy for the 'concepts versus specifics' design issues of teacher education programmes identified by Gainsburg: exemplifying pedagogical principles in detail as part of university teaching provides role models for practice, enabling prospective teachers to engage in the type of teaching promoted by the university in a low-risk manner, emulating their teacher educators but with fewer demands for contingent action.

- A communities of practice framework underlines the necessity for prospective teachers to see themselves as teachers in the making, and to be supported in the development of an identity of teacher in their participation in placement. Our findings indicate that part of the support they require involves providing opportunities to reflect on early school placement as meaningful participation even if they are not able 
to teach in the way that experienced teachers do.

Overall, our research provides an insight into the challenges of school placement for prospective teachers and the inevitable tensions that arise. Making space for reflecting on these tensions with both mentors and prospective teachers may help to give more realistic expectations of what to expect in placement, both in terms of what prospective teachers can be expected to "know" and what they can expect to, and be expected to, put into practice as they develop as teachers. 


\section{References}

Arvold, B. (2005). Goals embedded in tradition: Springboards for mathematics teacher education. Paper presented at the 15th ICMI Study on the Professional Education and Development of Teachers of Mathematics, Águas de Lindóia, Brazil.

Barnes, Y., Cockerham, F., Hanley, U. \& Solomon, Y. (2013) 'How do mathematics teaching enhancement programmes 'work'?' in V. Farnsworth and Y. Solomon (eds) Reframing Educational Research: Resisting the "What Works" Agenda. London; RoutledgeS

Berliner, D. C. (1989). Implications of studies of expertise in pedagogy for teacher education and evaluation. In Proceedings of the 1988 educational testing service invitational conference, new directions for teacher assessment (pp. 39-65). Princeton, NJ: Educational Testing Service.

Biesta, G. (2012). Becoming educationally wise: Towards a virtue-based approach to teaching and teacher education. In A. L. Østern, K. R. Smith, T. Krüger \& M. B. Postholm (Eds.), Teacher education research between national identity and global trends NAFOL Year Book 2012 (pp. 29-53). Trondheim: Akademika Publishing.

Bjerke, A. H., Eriksen, E., Rodal, C., Smestad, B., \& Solomon, Y. (2013a). Theorising mathematics teaching: Pre-service teachers' perceptions before and during school placement. In I. Pareliussen, B.B. Moen, A. Reinertsen, \& T. Solhaug (Eds.), FoU $i$ Praksis 2012 proceedings (pp. 20-27). Trondheim:Akademika Publishing.

Bjerke, A., Eriksen, E., Rodal, C., Smestad, B., \& Solomon, Y. (2013b). A tripartite cooperation? The challenges of school-university collaboration in mathematics teacher education in Norway. In A. M. Lindmeier, \& A. Heinze (Eds.), Proceedings of the 37th Conference of the International Group for the Psychology of Mathematics Education (Vol. 2, pp. 89-96). Kiel, Germany: PME

Boaler, J. (2003). Studying and capturing the complexity of practice - the case of the "dance of agency." In N. Pateman, B. Dougherty \& J. Zilliox (Eds.), Proceedings of the 27th conference of the international group for the Psychology of Mathematics Education (s. 316). Honolulu, Hawaii: PME.

Boaler, J., \& Humphreys, C. (2005). Connecting mathematical ideas: Middle school video cases to support teaching and learning. Portsmouth, NH: Heinemann.

Brown, C. A., \& Borko, H. (1992). Becoming a mathematics teacher. In D. A. Grouws (Ed.), Handbook of research on mathematics teaching and learning (pp. 209-239). New York: Macmillan Publishing Company.

Bullock, S. \& Russell, T. (2010). Does teacher education expect too much from field experience? In T. Falkenberg \& H. Smits (Eds.), Field experiences in the context of reform of Canadian teacher education programs (2 vols., pp. 91-100). Winnipeg, MB: Faculty of Education of the University of Manitoba.

Gainsburg, J. (2012). Why new mathematics teachers do or don't use practices emphasized in their credential program. Journal of Mathematics Teacher Education, 15(5), 359-379. doi:10.1007/s10857-012-9208-1

Grossman, P. L., Smagorinski, P., \& Valencia, S. W. (1999). Appropriating tools for teaching 
English: A theoretical framework for research on learning to teach. American Journal of Education, 108, 1-29.

Franke, M. L., Carpenter, T. P., Levi, L., \& Fennema, E. (2001). Capturing teachers' generative change: A follow-up study of professional development in mathematics. American educational research journal, 38(3), 653-689.

International Association for the Evaluation of Educational Achievement (IEA) (2012) Policy, Practice, and Readiness to Teach Primary and Secondary Mathematics in 17 Countries, retrieved 24/1/13 from http://teds.educ.msu.edu/wp-content/uploads/IEA_TEDS-M-InternationalReport1.pdf

Kværnes, L. (2013). Lærerstudenters utvikling mot det å bli matematikklærere. En empirisk beskrivelse og drøfting med fokus på en handlingsrettet lærerkompetanse. In: Pareliussen, I., Moen, B.B., Reinertsen A., Solhaug, T.: FoU i praksis 2012 conference proceedings, (pp. 136-144). Trondheim: Akademika forlag Trondheim.

Lave, J., \& Wenger, E. (1991). Situated learning: legitimate peripheral participation. New York: Cambridge University Press.

National Council of Teachers of Mathematics. (2000). Principles and standards for school mathematics. Reston, VA: Author.

Nasjonalt organ for kvalitet i utdanningen (NOKUT) (2006) Assessment of teacher education programmes in Norway. Retrieved 24/1/13 from http://www.nokut.no/Documents/NOKUT/Artikkelbibliotek/Norsk_utdanning/Evaluering/ alueva/ALUEVA_Hovedrapport.pdf

Nolan, K. (2008). Imagine there's no haven: Exploring the desires and dilemmas of a mathematics education researcher. In T. Brown (Ed.), The psychology of mathematics education: A psychoanalytic displacement (pp. 159-181). The Netherlands: Sense.

Nolan, K. (2012) Dispositions in the field: viewing mathematics teacher education through the lens of Bourdieu's social field theory. Educational Studies in Mathematics 80 (1-2), 201-216.

SINTEF (2008) Practice Learning and partnership models in teacher education in England, Wales, Finland and Norway. Retrieved 24/1/13 from http://www.sintef.no/upload/Teknologi_og samfunn/GSU/SINTEF\%20RAPPORT,\%20PI L-prosjektet_\%20200808.pdf,

Tatto, M., Lerman, S. \& Novotna, J. (2010) The organization of the mathematics preparation and development of teachers: a report from the ICMI Study 15, Journal of Mathematics Teacher Education 13, 313-324

Wenger, E. (1998). Communities of Practice. Cambridge: Cambridge University Press

Wenger, E. (2000). Communities of Practice and Social Learning Systems. Organization, 7(2), 225-246. doi:10.1177/135050840072002

Windschitl, M. (2002). Framing constructivism in practice as the negotiation of dilemmas: An analysis of the conceptual, pedagogical, cultural, and political challenges facing teachers. Review of Educational Research, 72(2), 131-175. 